\title{
Assessment of water quality of urban lakes for recreational purpose in thane district
}

\author{
Mayur Shirude, Ameya Gupte and, Bela Nabar \\ Post graduate Department of Microbiology, \\ Smt. C.H.M. College (University of Mumbai), \\ Ulhasnagar-421003, Dist. -Thane, Maharashtra India
}

\begin{abstract}
Manmade lakes are potential tourism site as well as a source of livelihood, urban lakes in Badlapur \& Kalva viz.Lotus pond \& Kalwa lake in thane district lakes were being used by the local communities residing nearby for various purposes such as farming/Irrigation purposes, fishing purposes, ecotourism, ash disposal, ganesh idol immersion purposes. Thus urban lakes in Badlapur \& Kalwa viz.Lotus pond \& Kalva lake in thane district were assessed for physical, chemical and bacteriological characteristics of the lake to assess quality of lake water for recreational purpose.

A total of nine samples of water from the lakes were collected for one year during the monsoon, pre - monsoon \& post monsoon seasons from a period of April 2012 to March 2013 and were subjected to physical, chemical and bacteriological analysis. The measured water quality parameters included $\mathrm{pH}$, color, turbidity, alkalinity, temperature, hardness, Specific conductivity, Dissolved oxygen, COD, BOD ,Chloride content TDS, Total load of bacteria, coliform count \& presence of human pathogens.

The biodiversity of the microorganisms was evaluated in the lake waters \& studied for the presence of nitrosifiers \& nitrifiers, sulfate reducers, cellulose degraders, phosphate solubilizers and sulfur oxidizers.

The baseline physico-chemical parameters were within the permissible limits. Both these lakes showed high $B O D \& C O D$ than the accepted limit. Thus Lake water is not potable, but can be used for general purpose as well as recreational purpose. Though the above lakes contain non-potable water , but it benefits ecology.
\end{abstract}

Key Words: BOD,COD, Coliforms, Lotus pond, Kalva Lake, Recreation

\section{INTRODUCTION}

Water is essential for life and the well being of all the people. Natural water systems provides fisheries, flood plains, agriculture, natural services and products like aquifer replenishment, water quality improvement and bio-diversity ${ }^{[1]}$. The use of water bodies for recreational purposes is one of the most important aspects of eco-tourism around the world. The main goal of the research was to assess the suitability of the urban Lake for recreational activities such as swimming, diving and boating to ensure the safety of users of the facility ${ }^{[2]}$. Specifically, the study assessed the bacteriological quality and some critical physico-chemical parameters of the water of the Lake for recreational purposes \& also for lively-hood. India is facing serious problems of natural reservoirs especially water, due to rapid population growth and economical conditions ${ }^{[3]}$. Lakes are also subjected to various natural processes taking place in the environment like the hydrologic cycle, with unprecedented developmental activities. Human beings are responsible for choking several lakes to death ${ }^{[4]}$. Run-off water is the common cause of the sewage entrance in the lake water. The idea behind choosing two lakes is to check the viability of urban lakes from residential and industrial area. The lotus pond is located $19^{\circ} 10^{\prime} 56.52^{\prime \prime} \& 73^{\circ} 13^{\prime} 21.68^{\prime \prime}$ in Badlapur and the Mafatlal Lake is located $20^{\circ} 56^{\prime} 33^{\prime \prime} \& 72^{\circ} 54^{\prime} 18^{\prime \prime}$ at Kalwa ${ }^{[5]}$. The lakes are surveyed for various aspects like its uses and human activities around the lakes and pollution. Lotus pond or "shiv-mandir lake". Lake situated in Belavaligoan near Badlapur region on Badlapur-Ambernath highway \& was covered by lotus flowers and water hyacinth is used for Lotus farming, Shingada(Trapa) farming. Small farms nearby the lake area were being well maintained by the farmers as they cultivated lady fingers and vegetables. The lake is not well maintained but used for idol immersions and ash disposal every year.

In Lotus pond cause of pollution is mainly general house-hold waste, plastic, thermacol and glass material. Mafatlal lake is situated close to Kalva station and Mafatlal factory, so these lakes are often called as "Kalva Lakes" or "Mafatlal Lakes". Fishing and vegetable farming is proving to be a good source of income for villagers. In Mafatlal Lake effluent from industry; pesticides from nearby fields, activities such as washing are main sources of pollution. Mafatlal Lake is used for washing clothes, utensils, animals. Fauna observed in the lake water of fishes such as such as Rohu, floral fish and Catla. The lake is surrounded by small farms, and the local people residing nearby the lake undertake farming and cultivate vegetables such as raddish, methi, spinach and cauliflower. 
Surface water samples under investigations were collected one time from three different sites each lake and composite sample is prepared and analyzed for the three different seasons.

\section{MATERIALS AND METHODS}

Sample collection:The lake water samples from urban lakes were collected monthly during premonsoon, monsoon and post-monsoon seasons. Water samples were collected in a clean 1 liter plastic container, which were rinsed with distilled water before collection. The containers were adequately labeled with the name, date, time of collection of water sample, for the records. After collection, the samples were protected from direct sunlight and transported in a cooler box containing ice packs to the laboratory for analyses. All samples were stored at $4^{\circ} \mathrm{C}$ and analyzed within $48 \mathrm{~h}$ of sample collection ${ }^{[6]}$.

* Total nine samples were collected and numbered as follows:

\begin{tabular}{ll}
\hline $\begin{array}{l}\text { Sample } \\
\text { Number }\end{array}$ & Site and season of sample \\
\hline 1A & Pre-monsoon sample Mafatlal Lake washing site \\
1B & Monsoon sample Mafatlal lake washing site \\
1C & Post-Monsoon sample Mafatlal lake washing site \\
2A & Pre-monsoon sample Mafatlal Lake vegetative \\
& site \\
2B & Monsoon sample Mafatlal Lake vegetative site \\
3A & Post-monsoon sample Mafatlal Lake washing site \\
3B & Pre-monsoon sample Shiv-Mandir Lake \\
3C & Monsoon sample Shiv-Mandir Lake \\
\hline
\end{tabular}

The physico-chemical and microbiological analysis of the above water samples were carried out. The analysis of the sample was carried out within four hours after the sampling. Highly unstable parameters such as $\mathrm{pH}$, temperature, opacity, dissolved oxygen, color etc. were recorded at the sampling site. The sampling was carried out monthly during pre-monsoon, monsoon and post-monsoon seasons. The parameters analyzed to assess the water quality are broadly divided into: Physical \& chemical parameters such as color, temperature, turbidity, specific conductivity, $\mathrm{pH}$, dissolved oxygen (DO), biological oxygen demand (BOD), chemical oxygen demand (COD), chlorides, hardness, alkalinity, total dissolved solids (TDS) and heavy metal concentrations of lead \& chromium were measured using Alpha model-4 atomic absorption spectroscopy (Chemtech Analytical Ltd, PN) with the use of an air-acetylene flame and single element hollow cathode lamp.

In bacteriological analysis Isolation, detection and estimation of coliforms, load of bacteria fungi \& enteric bacteria was studied. The presence of the beneficial flora in bioremediation of the lake was also assessed. The estimation of total heterotrophic bacteria was done on Nutrient agar, Sabourouds agar \& MacConkey agar plates within $24 \mathrm{~h}$ at $37^{\circ} \mathrm{C}$. Bacterial populations were expressed as colony forming units per milliliter (cfu/ml). Water samples were analyzed for MPN (Most Probable Number) it detects the number of coliforms present in the water. This test is the indication of sewage contamination. This test was carried out using standard protocol. The MPN can be determined by using a multiple tube technique to detect the number of coliforms by McCardy scheme.

Presence of E.coli was confirmed by IMViC test. Assessment of presence of nitrosifiers, nitrifiers, phosphate-solubilisers, sulfate-reducers, sulphur-oxidizers, cellulose digesters was carried out using enrichment $\&$ selective media selective. The biodiversity of the different microorganisms were studied in the lake water samples by microscopy \& standard biochemical methods.

\section{RESULTS AND DISCUSSION}

Central pollution Control Board has ascribed certain water quality standards for Inland water and according to these values water can be classified in five groups as mentioned below.

* Classification of Inland Surface Water According to standard values-

\begin{tabular}{llllll}
\hline Characteristics & A & B & C & D & E \\
\hline $\begin{array}{l}\text { Dissolved Oxygen } \\
\text { (mg/L) }\end{array}$ & 6 & 5 & 4 & 4 & - \\
$\begin{array}{l}\text { Biological Oxygen } \\
\text { Dissolved(mg/L) }\end{array}$ & 2 & 3 & 3 & - & - \\
\hline
\end{tabular}




\begin{tabular}{llllll}
\hline $\begin{array}{l}\text { Total Coliforms } \\
\text { MPN/100 ml }\end{array}$ & 50 & 500 & 5000 & - & - \\
$\begin{array}{l}\text { Total Dissolved } \\
\text { Solids }\end{array}$ & 500 & - & 1500 & - & 2100 \\
Chlorides (mg/L) & 250 & - & 600 & - & 600 \\
Color Hazen Units & 10 & 300 & 300 & - & - \\
Conductivity & - & - & - & 1000 & 2250 \\
(micromhos/c) & & & & & \\
Turbidity & - & - & $>25$ & - & - \\
pH & $6.5-$ & $6.5-8.5$ & $6.5-$ & $6.5-$ & $6.5-$ \\
& 8.5 & & 8.5 & 8.5 & 8.5 \\
\hline
\end{tabular}

\begin{tabular}{|l|l|}
\hline Designated best use & $\begin{array}{l}\text { Class of } \\
\text { water }\end{array}$ \\
\hline $\begin{array}{l}\text { Drinking Water Source without conventional } \\
\text { treatment but after Disinfection }\end{array}$ & $\mathrm{A}$ \\
\hline Outdoor bathing (Organised) & $\mathrm{B}$ \\
\hline $\begin{array}{l}\text { Drinking water source after conventional } \\
\text { treatment and disinfection }\end{array}$ & $\mathrm{C}$ \\
\hline Propagation of Wild life and Fisheries & $\mathrm{D}$ \\
\hline $\begin{array}{l}\text { Irrigation, Industrial Cooling, Controlled } \\
\text { Waste disposal }\end{array}$ & $\mathrm{E}$ \\
\hline
\end{tabular}

The above limits will help us ascertain the lakes under study. The water samples of the two lakes were assessed in three seasons. The results showed that all nine samples have an average $\mathrm{pH}$ of 7.2 which is generally within the range of 6.5 to 8.5 which is with the recommended guidelines of $\mathrm{CPCB}^{[7]}$.The $\mathrm{pH}$ is very important for recreational water quality because it has been proven that very low or high $\mathrm{pH}$ levels can cause skin and eye irritation.

Colour of water was found to be either pale yellow or grey, sometimes even colourless. The temperature of nine samples ranged between 20 to $30^{\circ} \mathrm{C}$ with an average value of $25^{\circ} \mathrm{C}$. This means that the water is suitable for recreational activities since there is scientific evidence that prolonged emersion in water warmer than 34 to $35^{\circ} \mathrm{C}$ is hazardous to humans. The turbidity of the nine samples ranged between 0.02 and 19 NTU while specific conductivity ranged between 124 to 398 are in the permissible limits of stipulated values in the WHO Guidelines for Safe Recreational Water and Environment (2003) requirement of 50 NTU and 400 respectively.

The TDS in the nine samples ranges from $110 \mathrm{mg} / \mathrm{l}$ to $193.8 \mathrm{mg} / \mathrm{l}$ which falls within the TDS guidelines for Inland surface water given by CPCB. Chloride content was found to be in the range of 15 to 85 $\mathrm{mg} / \mathrm{ml}$, which is within the permissible limit standards.

* Table showing DO and BOD values

\begin{tabular}{llll}
\hline $\begin{array}{l}\text { SAMPLE } \\
\text { NUMBER }\end{array}$ & $\begin{array}{l}\text { DO } \\
\text { DAY 1 } \\
(\mathbf{m g} / \mathbf{L})\end{array}$ & $\begin{array}{l}\text { DO } \\
\text { DAY 5 } \\
(\mathbf{m g} / \mathbf{L})\end{array}$ & $\begin{array}{l}\text { BOD } \\
\mathbf{m g} / \mathbf{L}\end{array}$ \\
\hline 1 & 38.40 & 17.6 & 20.8 \\
2 & 32 & 22.4 & 9.6 \\
3 & 12.8 & 9.6 & 3.2 \\
4 & 14.4 & 11.2 & 3.2 \\
5 & 22.4 & 11.2 & 11.2 \\
6 & 19.2 & 17.6 & 1.6 \\
7 & 51.2 & 43.2 & 8.0 \\
8 & 33.6 & 6.4 & 27.2 \\
9 & 32.6 & 5.4 & 26.2 \\
\hline
\end{tabular}

The DO and by inference the BOD is an indication of the level of biodegradable contaminant or pollutants in the water. A high level of DO means a low BOD and indicates a low level of organic contaminants or pollutant in the water. The BOD is high in all the samples except post-monsoon sample of Mafatlal Lake at the vegetative site. Sample no. 3 and 4 are just exceeding permissible value, while other samples are showing high BOD values in the range of 8 to 27.2, which is not recommended for good lake. The high BOD of the lake may be due to high organic load into the lake and hence DO levels are high. This indicates greater extent of pollution in water bodies. 
Table for Alkalinity and Hardness

\begin{tabular}{lll}
\hline $\begin{array}{l}\text { SAMPLE } \\
\text { NUMBER }\end{array}$ & $\begin{array}{l}\text { Alkalinity } \\
\text { mg/L }\end{array}$ & $\begin{array}{l}\text { HARDNESS } \\
\text { mg/L }\end{array}$ \\
\hline 1 & 250 & 820 \\
2 & 230 & 680 \\
3 & 220 & 730 \\
4 & 170 & 450 \\
5 & 180 & 480 \\
6 & 160 & 520 \\
7 & 110 & 550 \\
8 & 140 & 510 \\
9 & 130 & 500 \\
Std. limits & 200 & 300 \\
\hline
\end{tabular}

All Samples showed higher values of hardness which exceeds maximum permissible limits. At Washing-site of Mafatlal Lake people do wash clothes hence detergent contributes to hardness. Hardness is the property of water which prevents the lather formation with soap and increase the boiling point of waters. Calcium and magnesium dissolved in water are the two most common minerals that make water "hard" . The degree of hardness becomes greater as the calcium and magnesium content increases and is related to the concentration of multivalent cations dissolved in the water.

Alkalinity of water is its quantitative capacity to react with a strong acid to a designated $\mathrm{pH}$. Alkalinity of water is due to the presence of certain ions: carbonates, bicarbonates, and hydroxides in water. If the levels are higher or lower than this, there can be problems with water quality ${ }^{[7]}$.

Water sample 12 and 3 shows quite high alkalinity. While rest all sample do not exceed permissible limit.

* Table for Total Viable Count on different media(TVC)

\begin{tabular}{lll}
\hline $\begin{array}{l}\text { Sample } \\
\text { Number }\end{array}$ & $\begin{array}{l}\text { TVC on } \\
\text { Nutrient Agar } \\
\text { (cfu/ml)X10 }\end{array}$ & $\begin{array}{l}\text { TVC on } \\
\text { Sabouraud Agar } \\
\text { (cfu/ml)X10 }\end{array}$ \\
\hline 1 & 6266.6 & 5870.6 \\
2 & 777.6 & 728.33 \\
3 & 89.66 & 50 \\
4 & 4856.6 & 426.66 \\
5 & 340.6 & 721.33 \\
6 & 78.66 & 115 \\
7 & 679 & 234.66 \\
8 & 1806.6 & 543.33 \\
9 & 128.66 & 78.33 \\
\hline
\end{tabular}

Total viable count on nutrient medium and Sabouraud's agar shows that there is high load of microorganisms in the lakes.

* Table for Presence of Phosphate solubilizers and sulphate oxidisers.

\begin{tabular}{lccc}
\hline $\begin{array}{l}\text { Sample } \\
\text { Number }\end{array}$ & MPN & $\begin{array}{l}\text { Phosphate } \\
\text { Solubilizers }\end{array}$ & $\begin{array}{l}\text { Sulphate } \\
\text { Oxidiser }\end{array}$ \\
\hline 1 & 600 & + & + \\
2 & 800 & + & + \\
3 & 750 & + & + \\
4 & 900 & + & + \\
5 & 1100 & + & + \\
6 & 1000 & + & + \\
7 & 700 & + & + \\
8 & 800 & + & + \\
9 & 900 & + & + \\
\hline
\end{tabular}


All the water samples show the presence of phosphate solubilizers and sulphate oxidizers. Indicating beneficial flora in the lake waters. All the water samples showed presence of coliforms in the range of 600 to 1100 which indicates high level of sewage contamination. Thus as per the CPCB standards for MPN,the lake waters can be used for outdoor bathing source as well for drinking purpose after conventional treatment and disinfection.

Water samples were also analysed for presence of heavy metals like $\mathrm{Pb}^{+2}$ and $\mathrm{Cr}^{+2}$. But their concentration was within range of permissible limit. High concentration of heavy metals can lead to genetic problems in various organisms.

Thus to conclude the Shivmandir Lake as well as Kalwa Lakes can be used for recreational purposes \& for drinking after conventional treatment $\&$ disinfection after the analysis of the lake waters

\section{REFERENCES}

[1]. Banadda N.(2011) Characterization of non point source pollutants and their dispersion in Lake Victoria Uganda. African Journal of Environmental Science and Technology Vol. 5(2), pp. 73-79, February, ISSN 1996-0786.

[2]. Bureau of Indian Standards 'Lake Water - Specification' (First revision) September , 1991, BIS, New Delhi.

[3]. Garg R K, Rao R J and Saksena D N, J Environ Biology ( 2009), 30(5),909-916.

[4]. Standard Methods for the Examination of Water and Wastewater (1999) by American Public Health Association, American Water Works Association, Water Environment Federation 5210

[5]. http://www.panoramio.com/photo/68428314

[6]. Rao V.V.S., Mitsuo ,B.A. Prakash, S.V.N. Chandrasekhar, and K. Mahesh Kumar (2004) Potentially Toxic Elements (PTEs) Contamination in Hussainsagar Lake, Hyderabad The 11th National Symposium on Hydrology National Institute of Hydrology, Roorkee (India), November 22-23.

[7]. Water quality standards for surface water given by Central Pollution Control Board Indiacpcb.nic.in/NewItem 116 Guidelinesof\%20waterqualitymonitoring. 